American Journal of Economics and Business Administration 2 (4): 350-359, 2010

ISSN 1945-5488

(C) 2010 Science Publications

\title{
The Impact of Foreign Ownership on Firm Performance, Evidence from an Emerging Market: Turkey
}

\author{
Ali Osman Gurbuz and Asli Aybars \\ Department of Business Administration, \\ Faculty of Economics and Administrative Sciences, \\ Marmara University, Turkey
}

\begin{abstract}
Problem statement: The inflows of foreign direct investment are important sources of finance for developing countries. Due to the increase in the amount of the international flows of capital over the last three decades, the issue of the possible impact of foreign direct investment on the performance of corporations and thus the economy has gained increased attention. The purpose of this study is to explore how the financial performance of the companies listed on the Istanbul Stock Exchange (ISE) is affected by foreign ownership. Approach: This study employed panel data analysis on a sample of 205 non-financial listed companies covering the 3 year time period from 2005-2007. After having examined previous empirical work, several firm and industry related variables are included to eliminate the likely impact of other factors on corporate financial performance and to accurately demonstrate whether there are any significant differences in the financial performance of the firms due to foreign ownership. We also take into account the existence of a potential reverse relationship and conduct causality tests between the measures of financial performance and percentages of foreign ownership. Results: The results indicated that minority foreign-owned companies (MIN) perform better than domestic ones (DOM) in terms of operating profitability. When return on assets is employed as a performance measure, it is observed that MIN perform better than both DOM and majority foreign-owned companies (MAJ). It is also found that MAJ perform worse than DOM. The results of further analyzed, which employ yearly dummies for different ownership structures, are also provided. Conclusion: The overall results of this study indicated that foreign ownership improves firm financial performance in Turkey up to a certain level, beyond which additional ownership by the foreigners does not add to firm profitability. As it is obvious that the recent financial crisis will reduce the amount of international movement of capital, it is important to analyze the case prior to the crisis to be better able to gauge the possible impact of the lack of these inflows on companies in 2009 and onwards.
\end{abstract}

Key words: Foreign direct investment, multinationality, financial performance, emerging market, panel data analysis

\section{INTRODUCTION}

The world economic system has been restructured by the increase in the international flows of capital which take the form of Foreign Direct Investments (FDI), foreign portfolio investments and loans. It has been observed that direct exports are gradually being replaced by the sales of foreign affiliates in the host countries. This phenomenon leads to the replacement of international trade by FDI.

Due to the significance of the share of FDI among the other forms of international flows; many studies have been conducted in literature, each investigating some different aspect of the topic. Most of the studies have followed a macro perspective with the emphasis usually on the home and host country effects and determinants of FDI. The spillover issues have also gained much attention. However, studies that employ a micro perspective focusing on individual companies have been less abundant in previous literature. Therefore, this study aims to fill a gap; especially in the case of emerging markets.

As FDI is a crucial element of the financing decisions of developing countries, the possible impact of FDI on the performance of corporations and thus the economy has to be analyzed to enable the policymakers

Corresponding author: Ali Osman Gurbuz, Department of Business Administration, Faculty of Economics and Administrative Sciences, Marmara University, Turkey 
to follow the right course of action. Certain factors make Turkey an important case study. First, the share of developing countries as recipients of foreign flows has been gaining importance, especially over the last three decades and Turkey has been an important player among developing nations due to the size of its economy and potential. The second factor relates to the health and stability of the Turkish economy. The inflows of FDI to Turkey are projected to be relatively more stable than those of other emerging markets in the near future as a result of the precautionary actions taken after the financial crisis in 2001.

The remainder of the study is organized as follows: the following section provides information regarding the recent literature about the relationship between multinationality and firm financial performance. Then, the data, sample selection and the variables employed are set out. Materials and methods are revealed in the subsequent section. Lastly the results are evaluated and concluding remarks are provided together with theoretical and managerial implications.

Recent literature relating to the relationship between multinationality and firm financial performance: Many scholars have recently been investigating the relationship between multinationality and the performance of the firm because of the increase in the amount of overseas investment in the world economy. However, no consensus has been reached in spite of the vast amount of empirical work. According to Gomes and Ramaswamy (1999), the reason for the lack of consistent findings relates to the fact that the costs of internationalization have been ignored by the early researchers and that the relationship has not been analyzed across time. The individual strategies of firms also add to the complexity of the relationship (Kotabe et al., 2002). In their work, Geringer et al. (1989) show that the diversification strategy of the firm affects its performance. Specifically, related diversification leads to superior performance. Furthermore, the results indicate that a threshold exists beyond which the increase in the degree of internationalization no longer results in better performance (Geringer et al., 1989). The remainder of this section is dedicated to previous empirical research that was instrumental in the development of the model that forms the analytical core of this study.

A study conducted by Globerman et al. (1994) assesses the performance of domestic and foreignowned establishments in Canada. As a result of their empirical work, they conclude that there is no significant difference between the productivity of these two types of establishments once factors like size and capital intensity are controlled for. However, they state that the efficiency and income levels in Canada are increased by FDI because of the tendency of foreign firms to pay higher wages to production workers (Globerman et al., 1994).

Kim and Lyn (1990) examine the firms operating in the US to gauge whether there are any differences in the performance of foreign and domestic companies. They provide empirical evidence that domestic firms are more profitable in terms of return on equity after taxes, indicating that foreigners invest in the US to take advantage of the technological and economic prospects. Foreign multinationals are also found to be less efficient in terms of asset management which can be shown by their lower turnover ratios than their domestic counterparts. When the performance of the foreign firms are evaluated on the basis of the country of origin, Western European firms are measured to be the most profitable and efficient ones (Kim and Lyn, 1990).

Boardman et al. (1997) analyze the profitability differences between domestic firms and MNE subsidiaries in Canada from the perspective of agency costs. They find foreign subsidiaries to be more profitable and productive than their domestic counterparts. Upon further analysis they conclude that the effects of agency are the sources of the performance premium, with more concentrated ownership leading to improved performance (Boardman et al., 1997).

Gugler (1998) tests the association between firm profitability and ownership structure by focusing on the effect of ownership concentration and identity on a sample of non-financial Austrian companies. The results indicate a significant and negative relationship between ownership concentration and profit margin. However, foreign ownership is found to improve firm profitability (Gugler, 1998).

Oulton (1998) investigates whether manufacturing and non-manufacturing foreign-owned companies are more productive than domestically-owned companies in the UK. The results indicate that productivity is increased by US ownership in both the manufacturing and non-manufacturing companies by 26 and 34\%, respectively. A rise in production is also noticed by non-US foreign ownership with a $14 \%$ increase in manufacturing and a $31 \%$ increase in nonmanufacturing companies (Oulton, 1998).

Blomstrom and Sjoholm (1999) explore the differences in labor productivity between foreign and domestic companies in India. They find foreign ownership to be a statistically significant determinant of firm productivity alongside the level of capital intensity, the skill of the labor force, capacity utilization and operational scale. When foreign firms are further 
investigated, no statistically significant difference is observed between minority and majority levels of foreign ownership in terms of productivity. They further analyze the spillover effect of the foreign corporations and the results reveal that the productivity of domestic firms are positively affected by foreign presence again with no statistically significant difference between the minority and majority levels of foreign ownership (Blomstrom and Sjoholm, 1999).

Chhibber and Majumdar (1999) emphasize that the nature of the relationship regarding the decision to license, franchise, take part in a joint venture or entirely own a foreign company is an important strategic choice. As a result of their empirical analysis, they conclude that foreign firms with a $50 \%$ or greater foreign shareholding perform better than firms with minority foreign shareholdings and domestic firms in terms of return on sales and return on assets.

Djankov and Hoekman (2000) assert that technology transfer will result in an increase in productivity and use total factor productivity as an approximation for technology transfer. As a result of their study, they find FDI to have a significant and positive impact on the transfer of technology. Firms which are acquired by foreigners are found to have the highest level of growth in total factor productivity, while those without foreign partnerships are proven to exhibit the lowest growth rate in this measure (Djankov and Hoekman, 2000).

Konings (2001) uses firm level panel data to explore whether the financial performance of foreignowned subsidiaries is better than that of domestic firms in three emerging economies. Log of output is used as an indicator of performance and the results of the analysis reveal that foreign firms do not perform better than domestic ones in Bulgaria and Romania. However, a positive and significant effect of foreign ownership on firm productivity is observed in Poland. This finding is explained by the time it takes for foreign ownership to have an impact on performance due to delays in restructuring (Konings, 2001).

A research study performed by Gedajlovic et al. (2005) evaluates the impact of ownership structure on the financial performance and investment behavior of firms in Japanese manufacturing industries. They assert that foreign ownership, which is approximated by the percentage of outstanding shares held by foreign investors, is positively and significantly related to dividend payout. They further conclude that there is a negative and marginally significant relationship between foreign ownership and capital expenditures. However, no relationship is observed between ROA, as an indicator of profitability and foreign ownership (Gedajlovic et al., 2005).
Wiwattanakantang (2001) evaluates the impact of controlling shareholders on the financial performance of firms in Thailand. As a result of the analysis, he concludes that firms with controlling shareholders are better performers in terms of accounting-based measures, namely ROA and sales-assets ratio. However, no significant difference in performance is observed in terms of Tobin's Q. They further compare the performance of the firms with an emphasis on different types of controlling shareholders. This comparison finds empirical evidence that family-owned companies, foreign-controlled companies and firms with more than one controlling shareholder are better in terms of ROA than firms without controlling shareholders (Wiwattanakantang, 2001).

Dimelis and Louri (2002) perform an empirical analysis to examine the effect of different levels of foreign ownership on the labor productivity of manufacturing firms, proxied by output per worker. As a result of the empirical study, which employs quantile regression analysis, they conclude that majority ownership by foreigners does not have a significant effect on output per worker for the very productive or least productive firms. However, majority ownership is found to be positively and significantly related to output per worker in the middle-productivity range (Dimelis and Louri, 2002).

Munday et al. (2003) conduct a panel data analysis covering the period between 1994 and 1998 to compare the profitability of domestic firms and foreign subsidiaries in the UK. Two profit variables, namely, return on total capital employed and profit margin, are employed to assess the performance of the firms. The results evidence the relatively poor profit performance of foreign subsidiaries in the manufacturing sector with the Japanese being the worst performers (Munday et al., 2003).

Yudaeva et al. (2003) analyze the productivity of Russian firms with regard to the differences between the ones that are fully domestically-owned and at least partially foreign-owned. The results of their study indicate that foreign firms are more productive than domestic ones. They reason that the difference in efficiency can be due to the benefits that accrue to those firms from their foreign owners in terms of managerial experience, Research and development investments and distribution networks. The ease of access to foreign credit markets is defined as another factor that contributes to the productivity of foreign-owned firms. However, they also conclude that there is no statistically significant difference between the productivity of firms based on the percentage of foreign ownership (Yudaeva et al., 2003). 
Barbosa and Louri (2005) conclude that performance of firms in Portugal is not affected by foreign ownership after controlling for firm and industry specific characteristics. However, they find ownership by foreign investors to have a positive and significant effect on the profitability of firms in Greece measured by gross return on assets in the upper quantiles of the profitability measure (Barbosa and Louri, 2005).

Douma et al. (2006) analyze the effect of foreign ownership on the financial performance of Indian corporations with a distinction between foreign institutional and foreign corporate shareholders. They find that foreign firms perform better than domestic ones in terms of Return On Assets (ROA) and Tobin's Q. Upon further analysis, they conclude that ownership by foreign corporations has a positive and significant impact on both performance measures. When the results for foreign institutional investors are analyzed, no significant relationship is observed in terms of ROA. However, these investors have a positive and significant impact on Tobin's $\mathrm{Q}$ and this impact is larger than that of foreign corporate shareholders. Thus, the researchers conclude that foreign institutional investors may be investing in firms that are already better in terms of market returns (Douma et al., 2006).

Data and sample selection: The data used in this study is obtained from the publicly available database of the Istanbul Stock Exchange (ISE). The annual reports that display the shareholding structures, the financial statements, the footnotes to these statements and any other data relating to the dividend policies and exporting and importing behavior of the companies are collected from the database on a yearly basis for each firm. The data set consists of the nonfinancial companies listed on the ISE covering the time span of 3 years over the 2005-2007 period. Some companies are omitted due to a lack of data. Previous years are not included in this study to prevent any distortion that may result from the application of Inflation Accounting Practices in Turkey. The high inflation rates experienced in Turkey between 1950s and 2000 s can prevent financial statements from presenting comparable information. Therefore, inflation accounting practices are accepted to be applied since the beginning of 2004 to provide reliable information even during periods of high inflation.

Table 1: Summary of the variables, abbreviations and definitions

The dependent variables

\begin{tabular}{|c|c|}
\hline EBITTA & The ratio of earnings before interest and tax to total assets \\
\hline ROA & The ratio of net income to total assets \\
\hline \multicolumn{2}{|c|}{ The explanatory variables } \\
\hline FDIPERCENT & The percentage of shares that are owned by foreigners \\
\hline MIN & $\begin{array}{l}\text { A dummy variable equal to unity if foreigners own } 50 \% \text { or less of the shares of the company (but more } \\
\text { than } 10 \% \text { ) and otherwise equal to zero }\end{array}$ \\
\hline MAJ & $\begin{array}{l}\text { A dummy variable equal to unity if foreigners own more than } 50 \% \text { of the shares of the company and } \\
\text { otherwise equal to zero }\end{array}$ \\
\hline MIN2005 & $\begin{array}{l}\text { A dummy variable equal to unity if the foreigners own } 50 \% \text { or less of the shares of the company (but more } \\
\text { than } 10 \% \text { ) in year } 2005 \text { and otherwise equal to zero }\end{array}$ \\
\hline MIN2006 & A dummy variable equal to unity if the foreigners own $50 \%$ or less of the \\
\hline MIN2007 & $\begin{array}{l}\text { A dummy variable equal to unity if the foreigners own } 50 \% \text { or less of the shares of the company (but more } \\
\text { than } 10 \% \text { ) in year } 2007 \text { and otherwise equal to zero }\end{array}$ \\
\hline MAJ2005 & $\begin{array}{l}\text { A dummy variable equal to unity if the foreigners own more than } 50 \% \text { of the shares of the company in year } \\
2005 \text { and otherwise equal to zero }\end{array}$ \\
\hline MAJ2006 & $\begin{array}{l}\text { A dummy variable equal to unity if the foreigners own more than } 50 \% \text { of the shares of the company in year } \\
2006 \text { and otherwise equal to zero }\end{array}$ \\
\hline MAJ2007 & A dummy variable equal to unity if the foreigners own more than $50 \%$ of the shares \\
\hline Dom 2005 & $\begin{array}{l}\text { A dummy variable equal to unity if the firm is fully domestically owned or the share of the company in year } \\
2007 \text { and otherwise equal to zero foreign ownership is less than } 10 \% \text { in the year } 2005\end{array}$ \\
\hline DOM2006 & $\begin{array}{l}\text { A dummy variable equal to unity if the firm is fully domestically owned or the share of foreign ownership is } \\
\text { less than } 10 \% \text { in the year } 2006\end{array}$ \\
\hline \multicolumn{2}{|r|}{ A } \\
\hline SIZE & The log of net assets \\
\hline AGE & The number of years that passed since the establishment of the firm to the observation date \\
\hline DEBT & The ratio of long and short term debt to total assets \\
\hline CLTA & The ratio of current liabilities to total assets \\
\hline IMPCOGS & The ratio of imports to cost of goods sold \\
\hline EXPNETSALES & The ratio of exports to net sales \\
\hline DIVPAYOUT & The dividend payout ratio obtained from the ISE \\
\hline CAPINTENSITY & The ratio of net fixed assets to total assets \\
\hline INVTURNOVER & The ratio of cost of goods sold to average inventory \\
\hline CURRENTRA & The ratio of current assets to current liabilities \\
\hline NETSALESTA & The ratio of net sales to total assets \\
\hline
\end{tabular}


Finally, a balanced panel data set of 205 companies is employed, resulting in a final sample of 615 firm-year observations.

The variables: The variables employed in this study are determined based on previous empirical work and the specific conditions under which firms listed on the ISE operate. Table 1 displays the list of the dependent, explanatory and control variables together with their explanations.

\section{MATERIALS AND METHODS}

The use of the panel data in this study enables to conduct an analysis of many firms overtime by combining time-series and cross-sectional information. When the relationship between performance and foreign ownership is analyzed in a cross-sectional regression, the heterogeneity that is unobserved can cause to drive biased estimates due to the correlation between the variables and the error term. Panel data analysis is applied in this study following the works of Himmelberg et al. (1999) and Wintoki et al. (2010).

Three models are estimated for each dependent variable making up a total of 6 models to gauge the influence of foreign ownership on firm financial performance. In these models, only the explanatory variables employed are different; meaning that the same set of control variables are used for each model. The first type of models investigates the impact of foreign ownership denoted by the percentage of shares held by foreigners on the two different financial performance measures, which are the ratio of Earnings Before Interest and Tax to Total Assets (EBITTA) and Return On Assets (ROA). The second type of models takes a more detailed perspective and differentiates between minority and majority levels of foreign ownership. Thus, the analysis is conducted to examine whether companies that display foreign ownership within certain ranges outperform the domestic ones. In the last type of models, eight dummy variables, which are labeled as MIN2005, MIN2006, MIN2007, MAJ2005, MAJ2006, MAJ2007, DOM2005 and DOM2006, are generated to see the yearly influence of minority and majority foreign ownership on financial performance and explore whether they display superior performance compared to domestic firms. The estimation of these separate models is important because each one of them provides insight into the relationship between different measures of financial performance and foreign ownership from different perspectives. In order to have a better understanding of the models applied and the variables employed in these models, Table 2 is provided.

The issue of causality: The studies that investigate the impact of ownership structure on performance are confronted with the problem of a potential reverse relationship. This implies that the financial performance of a company can be affecting the ownership structure in that the explanatory variable referring to foreign ownership in the model can be determined simultaneously with the performance measure, which is originally the dependent variable. The first study that analyzed this reverse relationship was that of Demsetz (1983), who considered the ownership structure to be endogenously determined. He argues 'no single ownership structure is suitable for all situations if the value of the firm's assets is to be maximized' (Demsetz, 1983). The issue of treating the ownership structure as an endogenous variable is further stressed in the work of Demsetz and Villalonga (2001).

It has to be stated that the ownership structure of the companies that are the focus of this study are rather stable over the time period analyzed. However, following the work of Thomsen and Pedersen (2000), causality tests are conducted between each of the two variables that measure performance and the percentages of foreign ownership. In order to determine whether changes in performance affect the percentage of shares that are held by foreigners, a test is conducted to explore if the changes in the performance measure, which is the dependent variable in the original model, is a significant determinant of the foreign ownership in 2007. Thus, the equation for this test can be written as:

$$
\begin{aligned}
\text { FDI2007 }= & \text { Constant }+\beta . \quad \text { (change in performance } \\
& \text { measure btw 2005-2007) }
\end{aligned}
$$

Table 2: The models used in the analyses

\begin{tabular}{lll}
\hline Model & Dependent variable employed & Explanatory variable employed \\
\hline 1 & EBITTA & FDIPERCENT \\
2 & EBITTA & MIN, MAJ \\
3 & EBITTA & MIN2005, MAJ2005, DOM2005 \\
& & MIN2006, MAJ2006, DOM2006 MIN2007, MAJ2007 \\
4 & ROA & FDIPERCENT \\
5 & ROA & MIN, MAJ \\
6 & ROA & MIN2005, MAJ2005, DOM2005 \\
& & MIN2006, MAJ2006, DOM2006 MIN2007, MAJ2007 \\
\hline
\end{tabular}

*: The control variables employed are the same for all of the models and they can be listed as SIZE, AGE, DEBT, CLTA, IMPCOGS, EXPNETSALES, DIVPAYOUT, CAPINTENSITY, INVTURNOVER, CURRENTRA and NETSALESTA. They are not displayed on the table for each model to save space 
When this equation is applied for each measure of financial performance named as EBITTA and ROA, no significant relationship is observed between the changes in performance and the ownership structure. Thus, it can be stated that there is no problem in defining the structure of ownership as an exogenous variable in the model of this study. Alternatively, Vector Autoregression Model (VAR) can be used in this kind of analysis but due to the short time interval (3 years) it cannot be applied to this case.

\section{RESULTS}

In the results, the relationship between firm financial performance and foreign ownership is analyzed depending on the results obtained from Generalized Least Squares (GLS) corrected for heteroskedasticty and serial correlation. The Table 3 displays the outcomes of the analyses.

As the table represents, the control variables used in this study have certain significant impacts on firm performance and thus need to be discussed.

Table 3: The results of the analyses

\begin{tabular}{|c|c|c|c|c|c|c|}
\hline \multirow[b]{2}{*}{ Dependent variable } & \multicolumn{3}{|l|}{ EBITTA } & \multicolumn{3}{|l|}{$\mathrm{ROA}$} \\
\hline & Model 1 & Model 2 & Model 3 & Model 4 & Model 5 & Model 6 \\
\hline \multirow[t]{2}{*}{ SIZE } & $0.0196^{* * *}$ & $0.0207 * * *$ & $0.0215^{* * *}$ & $0.0220 * * *$ & $0.0229 * * *$ & $0.0227 * * *$ \\
\hline & (25.03) & (27.32) & $(30.88)$ & (19.23) & (23.18) & (20.53) \\
\hline \multirow[t]{2}{*}{ AGE } & $0.0003 * * *$ & $0.0002 * * *$ & $0.0004 * * *$ & $0.0003 * * *$ & $0.0002 * * *$ & $0.0003^{* * *}$ \\
\hline & (3.64) & $(2.68)$ & $(4.15)$ & $(2.81)$ & $(2.65)$ & (3.58) \\
\hline \multirow[t]{2}{*}{ DEBT } & $-0.0207 * * *$ & $-0.0244 * * *$ & $-0.0564 * * *$ & $-0.1095 * * *$ & $-0.1095 * * *$ & $-0.1140 * * *$ \\
\hline & $(-3.04)$ & $(-3.16)$ & $(-5.61)$ & $(-9.74)$ & $(-10.03)$ & $(-8.50)$ \\
\hline \multirow[t]{2}{*}{ CLTA } & $-0.1193 * * *$ & $-0.1065^{* * *}$ & $-0.0744 * * *$ & $-0.0746 * * *$ & $-0.0640 * * *$ & $-0.0579 * * *$ \\
\hline & $(-13.56)$ & $(-10.97)$ & $(-5.95)$ & $(-5.04)$ & $(-4.45)$ & $(-3.56)$ \\
\hline \multirow[t]{2}{*}{ IMPCOGS } & $-0.0201 * * *$ & $-0.0220^{* * *}$ & $-0.0297 * * *$ & $-0.0145^{* *}$ & $-0.0169 * * *$ & $-0.0190 * * *$ \\
\hline & $(-5.23)$ & $(-5.67)$ & $(-5.65)$ & $(-2.47)$ & $(-3.03)$ & $(-3.25)$ \\
\hline \multirow{2}{*}{ EXPNETSALES } & $-0.0492 * * *$ & $-0.0437 * * *$ & $-0.0405 * * *$ & $-0.0257 * * *$ & $-0.0228 * * *$ & $-0.0219 * * *$ \\
\hline & $(-10.41)$ & $(-9.29)$ & $(-7.06)$ & $(-3.98)$ & $(-3.58)$ & $(-2.78)$ \\
\hline \multirow[t]{2}{*}{ DIVPAYOUT } & $0.0017 * * *$ & 0.0017 *** & $0.0016^{* * *}$ & $0.0037 * * *$ & $0.0034 * * *$ & $0.0033^{* * *}$ \\
\hline & $(5.46)$ & $(5.55)$ & $(5.32)$ & $(7.59)$ & $(7.36)(8.05)$ & $(8.05)$ \\
\hline \multirow[t]{2}{*}{ CAPINTENSITY } & $-0.1178^{* * *}$ & $-0.1160^{* * *}$ & $-0.1174 * * *$ & $-0.1128 * * *$ & $-0.1124 * * *$ & $-0.1109^{* * *}$ \\
\hline & $(-21.08)$ & $(-19.49)$ & $(-23.50)$ & $(-12.09)$ & $(-12.45)$ & $(-11.58)$ \\
\hline \multirow[t]{2}{*}{ INVTURNOVER } & $0.0000 * * *$ & $0.0000^{* * * *}$ & $0.0000^{* *}$ & 0.0000 & 0.0000 & 0.0000 \\
\hline & $(4.07)$ & $(3.96)$ & $(2.54)$ & $(0.07)$ & $(0.04)$ & $(0.14)$ \\
\hline \multirow[t]{2}{*}{ CURRENTRA } & 0.0000 & 0.0000 & 0.0002 & -0.0003 & -0.0003 & -0.0005 \\
\hline & $(0.18)$ & $(0.48)$ & $(1.31)$ & $(-0.46)$ & $(-0.49)$ & $(-0.78)$ \\
\hline \multirow{2}{*}{ NETSALESTA } & $0.0195 * * *$ & $0.0181 * * *$ & $0.0182 * * *$ & $0.0109 * * *$ & $0.0082 * * *$ & $0.0088^{* * *} *$ \\
\hline & $(14.20)$ & $(11.47)$ & $(10.41)$ & $(4.95)$ & $(3.72)$ & $(3.89)$ \\
\hline \multirow[t]{2}{*}{ FDIPERCENT } & 0.0055 & & & $-0.0087 *$ & & \\
\hline & $(1.23)$ & & & $(-1.87)$ & & \\
\hline \multirow[t]{2}{*}{ MIN } & & $0.0172 * * *$ & & & $0.0172 * * *$ & \\
\hline & & $(3.92)$ & & & $(4.77)$ & \\
\hline \multirow[t]{2}{*}{ MAJ } & & 0.0030 & & & $-0.008 * *$ & \\
\hline & & $(0.69)$ & & & $(-1.97)$ & \\
\hline \multirow[t]{2}{*}{ MIN2005 } & & & $0.0140 * * *$ & & & 0.0028 \\
\hline & & & $(3.13)$ & & & $(0.37)$ \\
\hline \multirow[t]{2}{*}{ MIN2006 } & & & $0.0199 * * *$ & & & 0.0049 \\
\hline & & & $(4.37)$ & & & $(0.66)$ \\
\hline MIN2007 & & & $0.0184 * * *$ & & & $0.0137 *$ \\
\hline & & & $(3.48)$ & & & $(1.81)$ \\
\hline MAJ2005 & & & 0.0053 & & & -0.0024 \\
\hline & & & $(0.72)$ & & & $(-0.19)$ \\
\hline MAJ2006 & & & 0.0052 & & & 0.0071 \\
\hline & & & $(0.68)$ & & & $(0.56)$ \\
\hline MAJ2007 & & & -0.0019 & & & $-0.0503 * * *$ \\
\hline & & & $(-0.22)$ & & & $(-7.80)$ \\
\hline DOM2005 & & & $-0.0114 * * *$ & & & $-0.0137 * * *$ \\
\hline & & & $(-9.29)$ & & & $(-3.72)$ \\
\hline DOM2006 & & & $0.0117 * * *$ & & & $-0.0176^{* * *}$ \\
\hline & & & $(11.01)$ & & & $(-4.80)$ \\
\hline Constant & $-0.2379 * * *$ & $-0.2593 * * *$ & $-0.2745^{* * *}$ & $-0.2715 * * *$ & $-0.2899 * * *$ & $-0.2793 * * *$ \\
\hline & $(-16.31)$ & $(-17.93)$ & $(-19.78)$ & $(-13.29)$ & $(-16.29)$ & $(-13.73)$ \\
\hline Number of observations & 611.0000 & 611.0000 & 611.0000 & 612.0000 & 612.0000 & 612.0000 \\
\hline Number of groups & 204.0000 & 204.0000 & 204.0000 & 205.0000 & 205.0000 & 205.0000 \\
\hline Wald chi2 (19) & 2455.1900 & 2484.3100 & 3585.6100 & 1217.8500 & 1678.8100 & 1581.8500 \\
\hline Prob $>$ chi2 & 0.0000 & 0.0000 & 0.0000 & 0.0000 & 0.0000 & 0.0000 \\
\hline Log likelihood & 1272.5520 & 1273.5300 & 1229.4310 & 906.2679 & 904.1460 & 894.6246 \\
\hline
\end{tabular}


The results of the first model show that the operating profitability of the firm is positively and significantly affected by firm size $(\mathrm{z}=25.03, \mathrm{p}<0.01)$, which is consistent with previous empirical work. This means that larger firms perform better than smaller ones as a result of their competitive power and operational efficiency. The control variable AGE also has a significant and positive influence on operating profitability $(\mathrm{z}=3.64, \mathrm{p}<0.01)$. This finding is also consistent with the expectation that more experienced firm's exhibit superior performance. It has to be noticed that firm size positively affects the dependent variable EBITTA more than firm age which can be understood by the larger coefficient of the former.

The variables DEBT and CLTA have negative and significant effects on firm financial performance $(\mathrm{z}=-3.04, \mathrm{p}<0.01 ; \mathrm{z}=-13.56, \mathrm{p}<0.01$ respectively). These findings are likely caused by the fact that the increase in the amount of debt raises the costs associated with its fulfillment resulting in a decline in the profitability of the firm.

The coefficients of the variables IMPCOGS and EXPNETSALES are negative and significant $(z=-5.23$, $\mathrm{p}<0.01 ; \quad \mathrm{z}=-10.41, \quad \mathrm{p}<0.01$ respectively). The overvaluation of the Turkish Lira during the years 2005, 2006 and 2007 can provide an explanation for this phenomenon. The major reason why the firms engaged in imports during this period was the fact that imports of the inputs for production were relatively cheaper than the inputs that can be purchased in the domestic market due to exchange rates. Because the major motivation for imports was to provide inputs at a relatively lower price, production of higher quality products that generate higher profits was not guaranteed. Thus, the sign of the coefficient of IMPCOGS is found to be negative. Furthermore, in order to export their products, the firms engaged in fierce price competition resulting in low margins that disturbed profits. As a result, it can be stated that the overvaluation of the Turkish Lira also provides an explanation for the significant and negative coefficient of the control variable EXPNETSALES.

Another finding displayed in the Table 3 is the positive and significant impact of the variable DIVPAYOUT on the dependent variable EBITTA $(\mathrm{z}=5.46, \mathrm{p}<0.01)$. When firms distribute some of their earnings in the form of dividends, investors' expectation that firms will be profitable in the future is increased.

The capital intensity ratio of the firm, which provides some insight about industry-specific characteristics, has a negative and significant coefficient meaning that capital intensive firms that have more of their assets in the form of fixed assets perform worse than the others $(\mathrm{z}=-21.08, \mathrm{p}<0.01)$. This can be attributed to the high costs of capital in Turkey which prevent firms from improving their profitability.

The effect of the inventory turnover ratio of a company on its profitability is positive and significant but rather very small as can be understood from the coefficient of the variable $(\mathrm{z}=4.07, \mathrm{p}<0.01)$. This means that keeping too much inventory distorts firm financial performance.

The current ratio, which is labeled CURRENTRA, does not explain the variations in operating profitability which is illustrated by the insignificance of its coefficient.

The positive and significant coefficient of the control variable NETSALESTA indicates that the higher the efficiency of the firms in managing their assets, the better they perform $(\mathrm{z}=14.20, \mathrm{p}<0.01)$. This result implies that as firms take advantage of their assets, their profitability increases.

Interpretation of the data reveals that EBITTA is not statistically dependent on the percentage of shares that are owned by foreigners (FDIPERCENT) after controlling for the firm and industry specific characteristics. However, it is reasonable to consider that different levels of foreign ownership can have divergent impacts on financial performance and thus can distort the results, creating a spurious insignificant relationship between the performance measure and the explanatory variable FDIPERCENT. Therefore, the second model is developed to clearly analyze the impact of different levels of foreign ownership on firm financial performance.

Table 3 shows that the signs and the levels of significances of the control variables' coefficients in the second model are the same with those of the first one displaying no major difference in their magnitudes. Therefore, the explanations provided for the first model also hold true for the second one. The important issue to notice here is related to the significances of the coefficients of the variables MIN and MAJ. The coefficient of MIN is positive and significant meaning that firms that have no more than $50 \%$ foreign ownership perform better than the domestic ones, which are represented by the constant term $(\mathrm{z}=3.92, \mathrm{p}<0.01)$. However, the coefficient of the variable MAJ, which represents firms with more than 50\% foreign ownership, is statistically insignificant. Thus, it can be concluded that when the dominant factor in the ownership structure of the firm is the domestic investor, additional investments by the foreigners do not have a positive and significant impact on operating profitability. This finding explains why the explanatory 
variable FDIPERCENT is found to be insignificant in the first model.

In the third model for the dependent variable EBITTA, eight dummy variables are generated to determine if there are any yearly differences among the financial performances of minority foreign-owned, majority foreign-owned and domestic firms. In this model, the constant term represents the financial performance of the domestic firms in the year 2007 and acts as the benchmark of the model. The interpretation of the results on Table 3 reveals that minority foreignowned companies perform better than the domestic ones in all of the three years with the best performance occurring in 2006. The yearly coefficients of the majority foreign ownership structure are again insignificant providing further proof for the ineffectiveness of majority foreign ownership on the performance measure EBITTA. When this model is analyzed in terms of the control variables, it is seen that the signs and the levels of significances of the coefficients of the control variables are the same with the previous model with a reduction only in the significance of the coefficient of the variable INVTURNOVER $(\mathrm{z}=2.54, \mathrm{p}<0.05)$.

As the results of the fourth model employing ROA as the dependent variable indicate, the only insignificant control variables are INVTURNOVER and CURRENTRA. The signs of the coefficients of the remaining control variables and the levels of their significances are the same with those of the first model. Therefore, the explanations regarding the impact of the control variables on firm financial performance provided for the first model are also appropriate for the fourth one. However, it has to be noted that the signs of the coefficients stay constant but their magnitudes are a little higher than those in the first model. Furthermore, the explanatory variable FDIPERCENT deserves some interpretation as it has a negative and significant coefficient $(\mathrm{z}=-1.87, \mathrm{p}<0.10)$. This finding indicates that as the percentage of foreign ownership increases, the performance of the firms in terms of ROA deteriorates. Thus, it can be stated that the investment productivity is negatively affected by the increase in the percentage of shares held by the foreigners. Better understanding of the effect of foreign ownership on financial performance can be obtained with a more detailed analysis employing MIN and MAJ as the explanatory variables.

The fifth model is run to see whether the dependent variable ROA is affected by the minority and majority shares of foreign ownership. In this model, the constant term acts as the benchmark of the analysis and displays the impact of domestic ownership on financial performance. Evaluation of the results on Table 3 reveals that minority foreign ownership improves performance in terms of ROA $(\mathrm{z}=4.77, \mathrm{p}<0.01)$. However, the significant and negative coefficient of MAJ indicates that when the dominant shareholders are foreigners, firms display worse performance than the domestic ones and minority foreign-owned ones in terms of investment productivity $(\mathrm{z}=-1.97, \mathrm{p}<0.05)$. Because the signs and the levels of the significances of all of the control variables are the same with those of the first model, no further explanations regarding these variables are provided.

The yearly impact of minority and majority foreign ownership on firm performance in terms of ROA is analyzed in the sixth model. The constant term in this model represents the impact of domestic ownership on firm financial performance in the year 2007. The results on Table 3 show that 2007 is the only significant year to evaluate the foreign owners' effect on performance. This finding reveals that pooling the data in terms of minority and majority ownership, as in the fifth model, improves the explanatory power of the analysis. When the data is segregated in terms of years, as in the sixth model, the explanatory power decreases. The result shows that minority foreign-owned companies perform better than majority foreign-owned and domestic ones in $2007(\mathrm{z}=1.81, \mathrm{p}<0.10)$. Furthermore, the significant and negative coefficient of the explanatory variable MAJ2007 shows that majority foreign ownership distorts investment productivity $(\mathrm{z}=-7.80, \mathrm{p}<0.01)$ and domestic firms are found to demonstrate better performance than these companies.

\section{DISCUSSION}

There has long been a debate about the impact of FDI on the economies of recipient countries. One way to examine this phenomenon is to analyze financial performance of the companies with respect to their ownership structures and evaluate the relationship between foreign ownership and firm financial performance.

Even though numerous studies have been conducted in literature to investigate the relationship between certain aspects of ownership structure and financial performance, no consensus has been reached regarding the influence of foreign ownership on the performance of the firms. The findings of the analyses indicate that the existence of foreigners to a certain extent in the ownership structure improves firm profitability.

This detailed analysis is unique in that it covers a period of three years and is conducted on a total of 205 
listed companies in an emerging market. This analysis also employs a large set of control variables and different explanatory variables in each model to determine if there are differences between the performance of domestic and foreign companies and if different ranges of foreign ownership impact firm performance. Furthermore, the fact that the issue of causality is also taken into account adds to the uniqueness of the study.

\section{CONCLUSION}

This study runs two different sets of models, each employing a different dependent variable, to capture whether the existence of shares held by foreigners affects financial performance of the firms.

In the first set of models, EBITTA is used as the dependent variable to measure the operating profitability of the firms. The results of the first model indicate that there is no significant relationship between EBITTA and the explanatory variable FDIPERCENT. However, further analysis proves this insignificant relationship to be spurious due to the divergent impacts of different levels of foreign ownership on financial performance. In the second model, minority foreignowned companies are found to be more profitable than domestic ones. The insignificant coefficient of the explanatory variable MAJ shows that when domestic investors form the majority of the ownership structure, additional investments by the foreigners do not add to the operating profitability of the firm. The yearly analysis in the third model also affirms these findings. These results show that ownership of the shares of a company by foreigners is crucial in terms of improving performance due to the know-how, skills and technologies introduced to the firm in the host country, but the results also show that this effect erodes beyond a certain level of ownership. It can be asserted that this effect is due to the fact that there are certain unique ways of conducting business in Turkey that continue to make domestic relationships valuable and allow for domestic ownership to play a significant role.

ROA is employed as the dependent variable of the second set of models. It is found that an increase in foreign ownership deteriorates the investment productivity of the firms. However, the fifth model shows that this negative impact arises because of the significant and negative impact of majority foreign ownership on firm financial performance with MIN performing better than both domestic firms, as indicated by the constant term and MAJ. In this model, majority foreign owned companies are found to be the worst performers. The yearly analysis indicates that 2007 is the only significant year with the results being the same as those of the previous model.

The overall results of this study indicate that foreign ownership improves firm financial performance in Turkey up to a certain level, beyond which additional ownership by the foreigners does not add to firm profitability. Local bonds and relationships among domestic companies, their owners and their managers provide some advantages to domestically-owned firms that cannot be attained by majority foreign-owned companies. Thus, it can be concluded that the effect of FDI on Turkish Companies are positive, so long as foreign companies invest in minority stakes in domestic firms.

\section{REFERENCES}

Barbosa, N. and H. Louri, 2005. Corporate performance: Does ownership matter? A Comparison of foreign-and-domestic-owned firms in Greece and Portugal. Rev. Ind. Org., 27: 73-112. DOI: $10.1007 / \mathrm{s} 11151-005-4920-y$

Blomstrom, M. and F. Sjoholm, 1999. Technology transfer and spillovers: Does local participation with multinationals matter? Eur. Econ. Rev., 43: 915-923. DOI: 10.1016/S0014-2921(98)00104-4

Boardman, A.E., D.M. Shapiro and A.R. Vining, 1997. The role of agency costs in explaining the superior performance of foreign MNE subsidiaries. Int. Bus. Rev., 6: 295-317. DOI: 10.1016/S09695931(97)00005-X

Chhibber, P.K. and S.K. Majumdar, 1999. Foreign ownership and profitability: Property rights, control and the performance of firms in Indian industry. J. Law Econ., 42: 209-238. DOI: 10.1086/467423

Demsetz, H. and B. Villalonga, 2001. Ownership structure and corporate performance. J. Corp. Finance, 7: 209-233. DOI: 10.1016/S09291199(01)00020-7

Demsetz, H., 1983. The structure of ownership and the theory of the firm. J. Law Econ., 26: 375-390. http://www.jstor.org/pss/725108

Dimelis, S. and H. Louri, 2002. Foreign ownership and production efficiency: A quantile regression analysis. Oxf. Econ. Pap., 54: 449-469. DOI: 10.1093/oep/54.3.449

Djankov, S. and B. Hoekman, 2000. Foreign investment and productivity growth in Czech enterprises. World Bank Econ. Rev., 14: 49-64. http://www.jstor.org/pss/3990034 
Douma, S., R. George and R. Kabir, 2006. Foreign and domestic ownership, business groups and firm performance: Evidence from a large emerging market. Strat. Manage. J., 27: 637-657. DOI: 10.1002/smj.535

Gedajlovic, E., T. Yoshikawa and M. Hashimoto, 2005. Ownership structure, investment behavior and firm performance in Japanese manufacturing industries. Org. $\quad$ Stud., 26: 17-35. DOI: 10.1177/0170840605046346

Geringer, J.M., P.W. Beamish and R.C. Dacosta, 1989. Diversification strategy and internationalization: implications for MNE performance. Strat. Manage. J., 10: 109-119. DOI: 10.1002/smj.4250100202

Globerman, S., J.C. Ries and I. Vertinsky, 1994. The economic performance of foreign affiliates in Canada. Can. J. Econ., 27: 143-156. http://www.jstor.org/stable/135807

Gomes, L. and K. Ramaswamy, 1999. An empirical examination of the form of the relationship between multinationality and performance. J. Int. Bus. Stud., 30: 173-187. DOI: 10.1057/palgrave.jibs.8490065

Gugler, K., 1998. Corporate ownership structure in Austria. Emprica, 25: 285-307. DOI: 10.1023/A:1006967517368

Himmelberg, C.P., R.G. Hubbard and D. Palia, 1999. Understanding the determinants of managerial ownership and the link between ownership and performance. J. Financ. Econ., 53: 353-384. DOI: 10.1016/S0304-405X(99)00025-2

Kim, W.S. and E.O. Lyn, 1990. FDI theories and the performance of foreign multinationals operating in the US. J. Int. Bus. Stud., 21: 41-54. DOI: 10.1057/palgrave.jibs.8490326

Konings, J., 2001. The effects of direct foreign investment on domestic firms: Evidence from firmlevel panel data in emerging economies. Econ. Transit., 9: 619-633. DOI: 10.1111/14680351.00091
Kotabe, M., S.S. Srinivasan and P.S. Aulakh, 2002. Multinationality and firm performance: The moderating role of marketing and R\&D capabilities. J. Int. Bus. Stud., 33: 79-97. DOI: 10.1057/palgrave.jibs.8491006

Munday, M., M.J. Peel and K. Taylor, 2003. The performance of the foreign-owned sector of UK manufacturing: Some evidence and implications for UK inward investment policy. Fiscal Stud., 24: 501-521. DOI: $10.1111 / \mathrm{j} .1475-$ 5890.2003.tb00093.x

Oulton, N., 1998. Labor productivity and foreign ownership in the UK. NIESR. http://www.niesr.ac.uk/pubs/searchdetail.php?Pub licationID=199

Thomsen, S. and T. Pedersen, 2000. Ownership structure and economic performance in the largest European companies. Strat. Manage. J., 21: 689-705. DOI: 10.1002/(SICI)1097-0266(200006)21:6<689::AIDSMJ115>3.0.CO;2-Y

Wintoki, M.B., J.S. Linck and J.M. Netter, 2010. Endogeneity and the dynamics of Internal corporate governance. SSRN. http://papers.ssrn.com/sol3/papers.cfm?abstract_id $=970986$

Wiwattanakantang, Y., 2001. Controlling shareholders and corporate value: Evidence from Thailand. Pac.Basin Finance J., 9: 323-362. DOI: 10.1016/S0927-538X(01)00022-1

Yudaeva, K., K. Kozlov, N. Melentieva and N. Ponomareva, 2003. Does foreign ownership matter? The Russian experience. Econ. Transit., 11: 383-409. DOI: 10.1111/1468-0351.00157 